\title{
FOREST EDGE EFFECTS ON THE PHYTOSOCIOLOGICAL COMPOSITION OF AN ARAUCARIA FOREST FRAGMENT IN SOUTHERN BRAZIL
}

\author{
Marcelo Callegari Scipioni ${ }^{1 *}$, Antonio Lunardi Neto ${ }^{2}$, Alexandre Siminski ${ }^{1}$, \\ Vanderlei dos Santos ${ }^{3}$ \\ ${ }^{1 *}$ Federal University of Santa Catarina, Department of Agriculture, Biodiversity and Forestry, Curitibanos, Santa Catarina, Brazil - \\ marcelo.scipioni@gmail.com*; alexandre.siminski@ufsc.br \\ ${ }^{2}$ Federal University of Santa Catarina, Department of Natural and Social Sciences, Curitibanos, Santa Catarina, Brazil - \\ antonio.lunardi@ufsc.br \\ ${ }^{3}$ State University of Santa Catarina, Graduate Program in Forestry, Lages, Santa Catarina, Brazil - vsantos.engflorestal@gmail.com
}

Received for publication: 17/03/2017 - Accepted for publication: 09/05/2018

\begin{abstract}
The Araucaria forests of Southern Brazil have been drastically reduced as a result of anthropic intervention and are currently found at different stages of succession. The objective of our study was to understand the influence of forest fragmentation on the phytosociological composition of its tree component. The composition of floristic groups of the tree component and their correlation with the edaphic and environmental variables in a fragment of the Araucaria Forest in the municipality of Curitibanos, state of Santa Catarina, Brazil was analyzed. A hundred and ten permanent continuous plots $\left(10 \mathrm{~m}^{2}\right)$ with forest edges of different origins and formation times were established for sampling. Trees with diameter $\geq 5 \mathrm{~cm}$ at breast height (DBH) were measured and identified. Using TWINSPAN, data were analyzed for species importance values (including indicator species) in the formation of floristic groups. Floristic similarities resulted in separating groups conditioned by the forest succession. The presence of the invasive species Pinus taeda L. and pioneer species at the forest expansion border contributed to the formation of a spatially cohesive group. The other areas did not show influence of edge effects, being in an initial secondary succession stage, dominated by Jacaranda puberula Cham. Low edaphic variation among the classes of lithosols in a flat relief had no influence on the formation of floristic groups.
\end{abstract}

Keywords: Forest succession, invasive species, edaphic variables.

\section{Resumo}

Efeito da borda florestal na composição fitossociológica de um fragmento florestal de Araucária no Sul do Brasil. As Florestas de Araucárias encontram-se fragmentadas por diversos impactos antrópicos em ambientes com diferentes estágios de sucessão. Para entender as variações fitossociológicas do componente arbóreo e a influência da fragmentação, um fragmento de Floresta Ombrófila Mista Montana, do município de Curitibanos (SC), foi estudado por meio de análise de grupos florísticos do componente arbóreo e correlação com variáveis edáficas e ambientais. Foram alocadas 110 parcelas permanentes $\left(10 \mathrm{~m}^{2}\right)$ contínuas influenciadas por bordas de diferentes origens e tempos de formação. As árvores com diâmetro $\geq 5 \mathrm{~cm}$ para altura do peito (DAP) foram mensuradas e identificadas. Os dados foram analisados pelo valor de importância das espécies e formação de grupos florísticos e suas respectivas espécies indicadoras pelo método TWINSPAN. Os agrupamentos de similaridades florísticas resultaram em grupos condicionados pela sucessão florestal. A presença de espécie invasora Pinus taeda L. e espécies pioneiras na borda da floresta contribuiu para formação de um grupo espacialmente coeso. As demais áreas não sofreram influência das bordas devido a uma sucessão secundária inicial dominada pela espécie Jacaranda puberula Cham.. A presença de relevo plano e a pouca distinção das variáveis edáficas entre as classes de solos litólicos não influenciaram na formação dos grupos florísticos.

Palavras-chave: Sucessão florestal, espécie invasora, variáveis edáficas.

\section{INTRODUCTION}

The overall forest cover by the subtropical forests with Araucaria has been drastically reduced over the last hundred years, making them one of the most threatened forest formations in Brazil. This forest type, called the Mixed Ombrophilous Forest (MOF) or Araucaria Forest, is characterized by the presence of tropical Afro-Brazilian and austral-antarctic Andean elements, with multiple plant species associations in various stages of succession. The forest canopy is made conspicuous by the tree species Araucaria angustifolia (Bertol.) Kuntze (LEITE, 2002). The Santa Catarina Forest and Floristic Inventory (IFFSC) estimates that the remaining MOF forest in this state represents only $22 \%$ of the original cover (VIBRANS et al., 2013).

FLORESTA, Curitiba, PR, v. 48, n. 4, p. 483-492, out/dez. 2018

Scipioni. M. C. et.al.

ISSN eletrônico 1982-4688 
Ecological succession and edge effects in the vegetation that is undergone anthropic interventions is still not well understood. The state of Santa Catarina is noticeable for predominance of secondary forests with a long history of logging, where selective tree harvesting, extensive livestock management, and opening of roads are the main internal impact factors, with agricultural crop cultivation, cattle farming, and forest plantations of such exotics as Pinus and Eucalyptus spp., external. These activities promote alterations in the tree species abundance and changes in the fauna/flora interactions, both biotic and abiotic, thus affecting ecological processes within the plant communities. Reestablishment of natural dynamics in such plant communities depends on the ability of specific functional groups to overcome adversities imposed by the local conditions and on the richness of species adaptable to development in the altered environment (REZNIK et al., 2012).

The edge effect is a direct consequence of forest fragmentation, impacting its structure by exposing the forest environment to altered microclimatic conditions and leading to changes in its composition, population structure, number of tree species (REZNIK et al., 2012), and, most importantly, local extinctions caused by invasion of exotic species that favor biodiversity loss. In such environments, the dynamic of change is more pronounced due to higher individual mortality rates at the forest edge (MURCIA, 1995).

In this context, studies on species distribution and floristic groups aid to our understanding of phytosociological relationships within fragmented forest communities, making more effective their monitoring and management with the aim of their conservation.

The objective of the present study was to analyze the phytosociology of the arboreal component in a forest fragment with distinct edges in a flat, drained terrain. The suggested hypothesis is that the fragmentation and proximity of the distinct forest edges may be directing formation of floristic groups with pioneer species. Edaphic variables were also studied to determine their role in the forest succession process.

\section{METHODOLOGY}

\section{Study area}

The study was a forest fragment of approximately eight ha, at the Curitibanos Campus of the Federal University of Santa Catarina (UFSC) (Figure 1). The area is constituted of tholeitic basalts of the Gramado Formation (Serra Geral Group, São Bento Supergroup, Lower Cretaceous Period) (WILDNER et al., 2014). Within the regional context, the relief is smooth-wavy to wavy; in the study area, smooth wavy to flat. The climate of the region is characterized by average annual temperature of $17{ }^{\circ} \mathrm{C}$, ranging from $18.1{ }^{\circ} \mathrm{C}$ to $22^{\circ} \mathrm{C}$. The average temperature of the coldest month is less than or equal to $13{ }^{\circ} \mathrm{C}$ and that of the hottest month exceeds $22{ }^{\circ} \mathrm{C}$. The precipitation is 1,600 to $1,900 \mathrm{~mm} . \mathrm{ano}^{-1}$. The climate is classified, according to Köppen, as humid subtropical $(\mathrm{Cfb})$, with the oceanic influence in the dry season and a temperate summer (ALVARES et al., 2013). The vegetation typology of the study area is that of the Mixed Ombrophilous Forest, located at the end of a montane altitudinal gradient at 1,100 m (IBGE, 2012). The fragment has three borders: one, limited by an open road and pastures formed more than 60 years ago; another, formed by a firebreak and a forest of Pinus taeda formed in the 90 's; the third, a humid area with native herbaceous vegetation.

\section{Data sampling}

For the analysis of the vegetation, 110 continuous plots of $100 \mathrm{~m}^{2}$, with trees (living and dead) and lianas of a diameter at breast height (DBH $-1.3 \mathrm{~m}$ ) greater than or equal to $5.0 \mathrm{~cm}$, were sampled (Figure 1). Bifurcated tree trunks were considered a single individual, with their diameter the sum of the basal area. The height of the trees was estimated by comparing the extension of the telescopic cable of a high pruning pole and by using reference trees measured with the TruPulse 200X laser rangefinder.

The canopy cover of the plots was estimated, from January to February 2013, using a spherical densiometer readings of the four cardinal points. The canopy opening variable was defined using the mean readings. Botanical material of the unidentified tree species was submitted for determination to taxonomic specialists, and botanical nomenclature was verified in the Flora List of Brazil (FLORA DO BRASIL 2020, 2016). Exsicates were incorporated in the herbarium of the Federal University of Santa Catarina, Campus Curitibanos (CTBS/UFSC).

The forest substrate was characterized by the physical and chemical properties of the soil. Surface soil sampling $(0-20 \mathrm{~cm})$ was performed according to the procedures suggested by Santos et al. (2013b). Trenches at depths of 0.5 to $1.3 \mathrm{~m}$ were used to determine soil classes according to the Brazilian Soil Classification System (SiBCS) (SANTOS et al., 2013a) and their correspondences in the World Reference Base for Soil Resources (USS Working Group WRB) and subsequently defined by probing with Dutch augers at 0.4 - $0.6 \mathrm{~m}$. Soil samples were analyzed at the Soil Laboratory of the Federal University of Santa Maria (UFSM) for the following chemical parameters: $\mathrm{pH}$ in $\mathrm{H}_{2} \mathrm{O}$, calcium $(\mathrm{Ca})$, magnesium $(\mathrm{Mg})$, aluminum $(\mathrm{Al})$, potassium $(\mathrm{K})$, phosphorus $(\mathrm{P})$, effective cation exchange capacity (ECEC), base saturation levels (V\%), Al saturation (\%), and organic matter (OM) 
(DONAGEMA et al., 2011). Morphological features of the soil horizons were described and the same chemical parameters used to study their composition. The granulometric composition of soil samples (DONAGEMA et al., 2011) was studied at the Chemical Laboratory of Federal University of Santa Catarina, Campus Curitibanos (CTBS/UFSC).

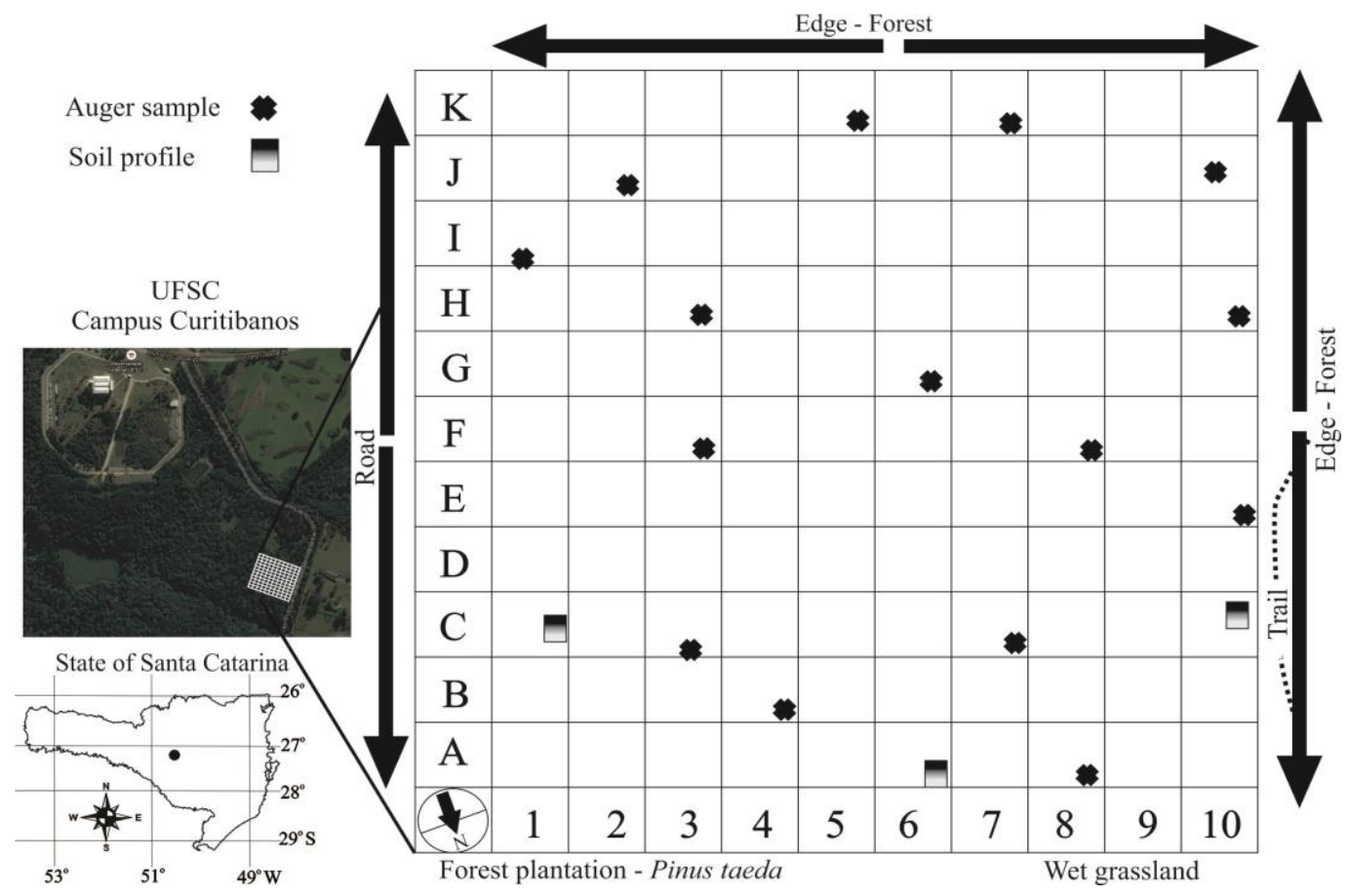

Figure 1. Study fragment of the Montane Araucaria Forest, municipality of Curitibanos, state of Santa Catarina, Brazil, with sampling plots locations.

Figura 1. Fragmento de Floresta Ombrófila Mista Montana estudado no município de Curitibanos, Santa Catarina, e a localização das parcelas para o levantamento fitossociológico.

\section{Data analysis}

The Two-Way Indicator Species Analysis (TWINSPAN) was used to identify floristic groups, indicator species, and spatial distribution of plots on the forest edges. The species abundance matrix by plots was analyzed. In the absence of an environmental relief gradient, the group divisions were defined with the eigenvalue $\geq 0,25$. The definition of groups was also based on the phytosociological composition of clusters, by observing the successional species change and using knowledge of the autoecology of the indicator species and species with the highest importance values. PC-ORD ver. 6.0 (MCCUNE; MEFFORD, 2011) was used for the grouping analysis.

In order to diagnose existence of environmental differences and significant variables in the formation of floristic groups, environmental and phytosociological parameters for the soil class and floristic groups were compared using mean values for each sampled plot in the One-way ANOVA analysis, with the post-hoc Tukey's test.

Species accumulation curves (CHAO et al., 2014) and sample coverage were used to assess the sampling adequacy in the iNEXT software package (CHAO et al., 2016). For data extrapolation, the species accumulation curve twice the sample size was used. Confidence intervals of the species accumulation curve, based on the 1,000 replications bootstrap, were $95 \%$.

The following phytosociological parameters were calculated according to Mueller-Dombois and Ellenberg (2002): density (AD), frequency (AF), absolute dominance (ADo) expressed by basal area, relative density (RD), relative frequency (R), coverage value (CV), and importance value (IV).

\section{RESULTS}

The relief of the study forest fragment was flat, characterized by absence of a topographic gradient, rock outcrops, and significant variation in the canopy opening between the soils classes. The soil texture ranged from clayey to very clayey. The stoniness of the soil was considered very stony, and the rockiness as rocky. The soils were classified as Neossolo Litólico (SiBCS)/Epileptic Regosol (Clayic) (WRB) and Cambissolo Húmico

FLORESTA, Curitiba, PR, v. 48, n. 4, p. 483-492, out/dez. 2018

Scipioni. M. C. et.al.

ISSN eletrônico 1982-4688 
(SiBCS)/Endoleptic Umbrisols (Clayic, Profundihumic) (WRB). There was no significant variation $(\alpha=0,05)$ in the chemical and granulometric composition, density, and basal area between the soil classes in the sampled plots, except for higher magnesium values in Cambisols (Table 1).

Table 1. Chemical and soil variables (sand, silt, and clay) $(0-20 \mathrm{~cm})$, canopy cover, tree density, and basal area of 110 plots in the study fragment of the Araucaria Forest, municipality of Curitibanos, state of Santa Catarina, Brazil.

Tabela 1. Variáveis químicas e granulométricas do solo $(0-20 \mathrm{~cm})$, abertura de dossel, densidade de árvores e área basal de 110 parcelas alocadas em um fragmento de Floresta Ombrófila Mista, em Curitibanos, Santa Catarina, Brasil.

\begin{tabular}{|c|c|c|c|c|c|}
\hline \multirow{2}{*}{$\begin{array}{l}\text { Environmental } \\
\text { variables }\end{array}$} & \multirow{2}{*}{$\begin{array}{l}\text { Neossolo } \\
n=44\end{array}$} & \multirow{2}{*}{$\begin{array}{l}\text { Cambissolo } \\
n=45\end{array}$} & \multirow{2}{*}{$\begin{array}{l}\text { Neossolo /Cambissolo } \\
n=21\end{array}$} & \multicolumn{2}{|c|}{ ANOVA } \\
\hline & & & & $F$ & $p$ \\
\hline $\mathrm{pH}\left(\mathrm{H}_{2} \mathrm{O}\right)$ & $3,90 \pm 0,21$ & $4,04 \pm 0,27$ & $3,95 \pm 0,26$ & 3,231 & 0,043 \\
\hline $\mathrm{P}(\mathrm{mg} / \mathrm{L})$ & $6,03 \pm 3,96$ & $5,52 \pm 2,47$ & $5,315 \pm 1,71$ & 0,499 & 0,608 \\
\hline $\mathrm{K}(\mathrm{mg} / \mathrm{L})$ & $70,40 \pm 20,63$ & $77,87 \pm 25,56$ & $70,40 \pm 18,59$ & 1,467 & 0,235 \\
\hline $\mathrm{OM}(\%)$ & $7,94 \pm 2,17$ & $6,86 \pm 1,42$ & $7,28 \pm 1,67$ & 3,991 & 0,021 \\
\hline $\mathrm{Al}(\mathrm{cmolc} / \mathrm{L})$ & $7,64 \pm 0,95$ & $7,22 \pm 1,11$ & $7,50 \pm 1,60$ & 0,623 & 0,538 \\
\hline $\mathrm{Ca}(\mathrm{cmolc} / \mathrm{L})$ & $0,58 \pm 0,37$ & $0,70 \pm 0,44$ & $0,73 \pm 0,83$ & 0,952 & 0,389 \\
\hline $\mathrm{Mg}(\mathrm{cmolc} / \mathrm{L})$ & $0,22 \pm 0,12^{\mathrm{a}}$ & $0,34 \pm 0,20^{b}$ & $0,28 \pm 0,21^{\mathrm{ab}}$ & 4,835 & 0,010 \\
\hline effective CEC & $8,63 \pm 0,82$ & $8,47 \pm 0,88$ & $8,69 \pm 0,97$ & 3,750 & 0,027 \\
\hline $\mathrm{V}(\%)$ & $2,70 \pm 1,53$ & $4,14 \pm 2,57$ & $4,00 \pm 4,88$ & 3,254 & 0,042 \\
\hline Clay $\left(\mathrm{g} \cdot \mathrm{kg}^{-1}\right)$ & $563,9 \pm 63,8$ & $555,6 \pm 67,2$ & $554,7 \pm 47,3$ & 0,254 & 0,776 \\
\hline Sand $\left(\mathrm{g} \cdot \mathrm{kg}^{-1}\right)$ & $69,9 \pm 27,9$ & $70,7 \pm 12,3$ & $67,4 \pm 17,0$ & 0,178 & 0,837 \\
\hline Silt $\left(\mathrm{g} . \mathrm{kg}^{-1}\right)$ & $366,0 \pm 59,8$ & $373,6 \pm 69,4$ & $377,8 \pm 48,1$ & 0,302 & 0,740 \\
\hline Canopy (open \%) & $20,94 \pm 6,94$ & $21,23 \pm 10,32$ & $19,47 \pm 6,97$ & 0,308 & 0,735 \\
\hline Tree/ha & $1445 \pm 629$ & $1555 \pm 592$ & $1361 \pm 682$ & 0,767 & 0,467 \\
\hline Basal area/ha & $35,0 \pm 14,8$ & $38,1 \pm 15,5$ & $36,7 \pm 21,0$ & 0,404 & 0,669 \\
\hline
\end{tabular}

Values are means \pm standard deviation of $\mathrm{n}$ samples of each soil class. In situations where the $F$ and $P$ test indicated significant differences between the soil classes, the averages followed by the same letter did not differ significantly from each other in the Tukey test $(\alpha=0,05)$, and the values without letters were not significant.

A total of 1,512 live trees, distributed in 29 botanical families, including 62 native tree species, one exotic species (Pinus taeda), and 99 unclassified dead individuals were sampled, amounting to 1,622 individuals in the 110 study plots with $40.32 \mathrm{~m}^{2}$ in the basal area $\left(\mathrm{DBH} \geq 10 \mathrm{~cm}: 920 \mathrm{ind} . / 37,16 \mathrm{~m}^{2}\right)$. Judging by the sampling and sample completeness curves (Fig. 2), the tree community representation was sampled sufficiently.
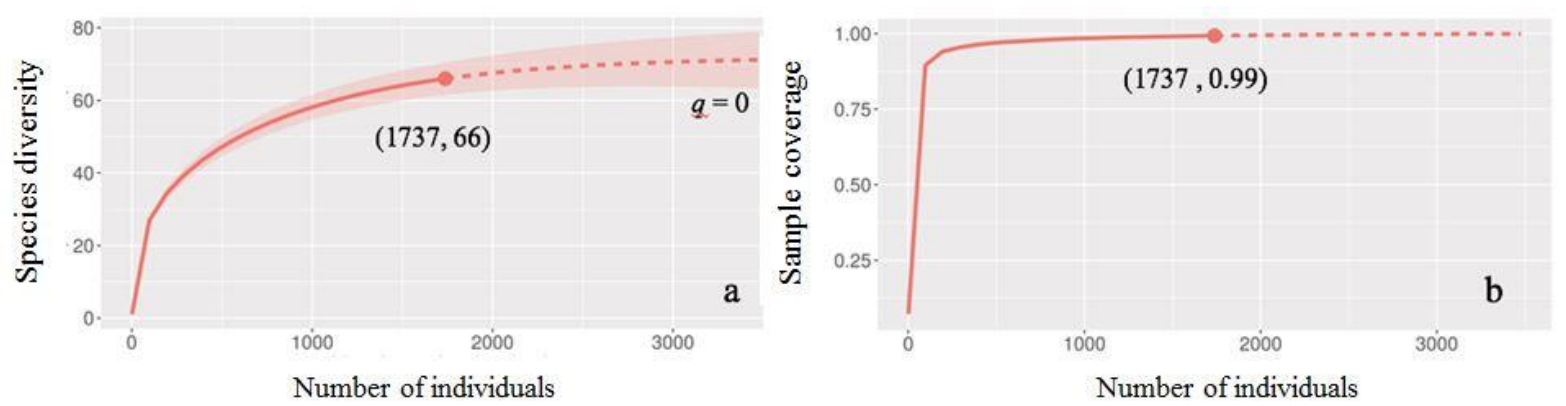

Figure 2. Sample-size-based rarefaction and extrapolation sampling curve (a) of the study fragment of the Araucaria Forest, municipality of Curitibanos, state of Santa Catarina, Brazil. Sample-size based rarefaction (solid line) and extrapolation (dashed line) up to double the reference tree sample size. The $95 \%$ confidence intervals represented by red-shaded areas. Sample completeness curve (b). Reference samples are indicated by solid dots

Figura 2. Curva de amostragem de rarefação e extrapolação baseada no tamanho da amostra (a) de um fragmento de floresta de araucária no município de Curitibanos, Santa Catarina, Brasil. Tamanho da amostra (linha sólida) e extrapolação (linha tracejada) até o dobro do tamanho da amostra de referência de espécies. Os intervalos de confiança de $95 \%$ são representados pelas regiões sombreadas vermelhas. Curva da cobertura da amostra (b). As amostras de referência são indicadas por pontos sólidos.

The most abundant families were Myrtaceae with 12 species, followed by Asteraceae (8), Aquifoliaceae (5), Lauraceae (4), Sapindaceae (3), and Fabaceae (3), representing 55.5\% of the species in the tree community. The tree species with the highest density were Jacaranda puberula Cham. (323 ind. ha ha $^{-1}$, 
Ocotea bicolor Vattimo-Gil (172 ind. ha ${ }^{-1}$ ), Casearia decandra Jacq. (123 ind. ha ${ }^{-1}$ ), and Calyptranthes concinna DC. (97 ind. ha ${ }^{-1}$ ), dominant in the lower strata of the forest fragment and representing $44.6 \%$ of the individuals. Standing dead trees and lianas represented $5.9 \%$ and $0.9 \%$ of sampled individuals per hectare, respectively.

The largest basal areas were those of the dominant canopy species: Araucaria angustifolia, Ocotea bicolor, and Matayba elaeagnoides Radlk (11,9\% basal area/ha). The Shannon diversity and Pielou equability indices were, respectively, $\mathrm{H}^{\prime}=3.00$ and $\mathrm{J}^{\prime}=0.72$. The high ecological dominance indicated by the Pielou index was influenced by the high values of relative density (RD) of Jacaranda puberula (Table 2). This species presented the highest importance value (IV), followed by Ocotea bicolor, Araucaria angustifolia, dead standing trees, Calyptranthes concinna, Vernonanthura discolor (Spreng.) H.Rob., Casearia decandra, Matayba elaeagnoides, and Ocotea puberula (Rich.) Nees, which, together, amounted to $64.8 \%$ of the cover value and $61.2 \%$ of the IV. The first three species were present in more than half of the plots.

Among the species with high IV, Araucaria angustifolia, Matayba elaeagnoides, and Vernonanthura discolor were also distinguished by their high basal area value. Larger trees dominated the forest canopy. Jacaranda puberula and Ocotea bicolor, both of medium size, showed high density and frequency, factors contributing to their valuations. Calyptranthes concinna and Casearia decandra, typical small-size species of the lower stratum, had high importance values due mainly to their high density and frequency. Dead standing trees, occupying the fourth IV position, represented an important component in the composition of the forest, with the diametric variation between 5 and $40 \mathrm{~cm}$ and the mean value of $16 \mathrm{~cm}$.

Table 2. List of tree species in the study fragment of the Araucaria Forest, municipality of Curitibanos, state of Santa Catarina, Brazil, with their phytosociological parameters and ranked by the importance value (IV).

Tabela 2. Espécies arbóreas e parâmetros fitossociológicos de um fragmento de Floresta Ombrófila Mista Montana, em Curitibanos, Santa Catarina, Brasil.

\begin{tabular}{|c|c|c|c|c|c|c|c|c|c|}
\hline Scientific name & AD & RD & ADo & RDo & $\mathbf{A F}$ & RF & IV & $\mathbf{H}$ & $\mathbf{H x}$ \\
\hline Jacaranda puberula Cham. & 323,8 & 20,2 & 3,527 & 8,8 & 69,1 & 8,9 & 37,9 & 6,8 & 13,5 \\
\hline Ocotea bicolor Vattimo-Gil & 172,3 & 10,7 & 3,729 & 9,3 & 51,8 & 6,7 & 26,7 & 8,1 & 20,0 \\
\hline Araucaria angustifolia (Bertol.) Kuntze & 65,3 & 4,1 & 4,601 & 11,5 & 45,5 & 5,8 & 21,4 & 10,8 & 27,0 \\
\hline Dead standing trees & 95,0 & 5,9 & 2,112 & 5,3 & 46,4 & 6,0 & 17,2 & 5,7 & 16,5 \\
\hline Calyptranthes concinna DC. & 97,0 & 6,0 & 1,563 & 3,9 & 55,5 & 7,1 & 17,1 & 5,8 & 12,0 \\
\hline Vernonanthura discolor (Spreng.) H.Rob. & 61,4 & 3,8 & 3,209 & 8,0 & 36,4 & 4,7 & 16,5 & 10,2 & 15,0 \\
\hline Casearia decandra Jacq. & 123,8 & 7,7 & 0,718 & 1,8 & 53,6 & 6,9 & 16,4 & 5,5 & 13,5 \\
\hline Matayba elaeagnoides Radlk. & 52,5 & 3,3 & 3,556 & 8,9 & 31,8 & 4,1 & 16,3 & 10,5 & 17,0 \\
\hline Ocotea pulchella (Nees \& Mart.) Mez & 48,5 & 3,0 & 2,882 & 7,2 & 30,9 & 4,0 & 14,2 & 11,4 & 25,0 \\
\hline Lamanonia ternata Vell. & 33,7 & 2,1 & 3,511 & 8,8 & 24,5 & 3,2 & 14,0 & 10,2 & 18,0 \\
\hline Zanthoxylum rhoifolium Lam. & 74,3 & 4,6 & 0,733 & 1,8 & 35,5 & 4,6 & 11,0 & 6,9 & 12,0 \\
\hline Clethra scabra Pers. & 46,5 & 2,9 & 1,616 & 4,0 & 24,5 & 3,2 & 10,1 & 7,7 & 17,0 \\
\hline Drimys brasiliensis Miers & 57,4 & 3,6 & 0,711 & 1,8 & 31,8 & 4,1 & 9,4 & 5,9 & 10,0 \\
\hline Myrcia palustres DC. & 30,7 & 1,9 & 0,911 & 2,3 & 25,5 & 3,3 & 7,5 & 7,5 & 13,0 \\
\hline Cinnamodendron dinisii Schwacke & 36,6 & 2,3 & 0,897 & 2,2 & 22,7 & 2,9 & 7,5 & 7,7 & 12,5 \\
\hline Pinus taeda $\mathrm{L}$. & 26,7 & 1,7 & 1,292 & 3,2 & 8,2 & 1,1 & 6,0 & 8,0 & 13,0 \\
\hline Annona rugulosa (Schltdl.) H.Rainer & 37,6 & 2,3 & 0,298 & 0,7 & 16,4 & 2,1 & 5,2 & 6,5 & 25,0 \\
\hline Ilex paraguariensis A.St.-Hil. & 18,8 & 1,2 & 0,376 & 0,9 & 15,5 & 2,0 & 4,1 & 7,8 & 15,0 \\
\hline $\begin{array}{l}\text { Myrsine coriacea (Sw.) R.Br. ex Roem. \& } \\
\text { Schult. }\end{array}$ & 23,8 & 1,5 & 0,108 & 0,3 & 12,7 & 1,6 & 3,4 & 6,8 & 12,0 \\
\hline Gymnanthes klotzschiana Müll.Arg. & 21,8 & 1,4 & 0,270 & 0,7 & 10,0 & 1,3 & 3,3 & 7,2 & 12,0 \\
\hline Lianas & 13,9 & 0,9 & 0,100 & 0,3 & 10,0 & 1,3 & 2,4 & 7,7 & 12,0 \\
\hline Sapium glandulatum (Vell.) Pax & 11,9 & 0,7 & 0,182 & 0,5 & 9,1 & 1,2 & 2,4 & 8,3 & 11,0 \\
\hline $\begin{array}{l}\text { Myrceugenia miersiana (Gardner) D.Legrand } \\
\text { \& Kausel }\end{array}$ & 12,9 & 0,8 & 0,164 & 0,4 & 8,2 & 1,1 & 2,3 & 5,9 & 11,0 \\
\hline Ocotea puberula (Rich.) Nees & 4,0 & 0,2 & 0,519 & 1,3 & 3,6 & 0,5 & 2,0 & 10,1 & 15,0 \\
\hline Piptocarpha angustifolia Dusén ex Malme & 5,9 & 0,4 & 0,364 & 0,9 & 5,5 & 0,7 & 2,0 & 10,4 & 27,0 \\
\hline Maytenus aquifolia Mart. & 7,9 & 0,5 & 0,160 & 0,4 & 7,3 & 0,9 & 1,8 & 5,5 & 7,5 \\
\hline Mimosa scabrella Benth. & 7,9 & 0,5 & 0,172 & 0,4 & 6,4 & 0,8 & 1,7 & 10,1 & 17,0 \\
\hline Ilex brevicuspis Reissek & 5,9 & 0,4 & 0,276 & 0,7 & 4,5 & 0,6 & 1,6 & 10,3 & 15,0 \\
\hline Prunus myrtifolia (L.) Urb. & 4,0 & 0,2 & 0,214 & 0,5 & 3,6 & 0,5 & 1,3 & 9,9 & 13,0 \\
\hline Scientific name & AD & RD & ADo & RDo & $\mathbf{A F}$ & RF & IV & $\mathbf{H}$ & $\mathbf{H x}$ \\
\hline Campomanesia xanthocarpa (Mart.) O.Berg & 5,9 & 0,4 & 0,071 & 0,2 & 5,5 & 0,7 & 1,2 & 8,1 & 10,0 \\
\hline
\end{tabular}

FLORESTA, Curitiba, PR, v. 48, n. 4, p. 483-492, out/dez. 2018

Scipioni. M. C. et.al.

ISSN eletrônico 1982-4688

DOI: $10.5380 /$ rf.v48i4.51281 
Myrcia oblongata DC.

Miconia hyemalis A.St.-Hil. \& Naudin

Inga lentiscifolia Benth.

Ilex theizans Mart. ex Reissek

Cupania vernalis Cambess.

Celtis iguanaea (Jacq.) Sarg.

Dasyphyllum spinescens (Less.) Cabrera

Myrceugenia euosma (O.Berg) D.Legrand

\begin{tabular}{|c|c|c|c|c|c|c|c|c|}
\hline 5,9 & 0,4 & 0,115 & 0,3 & 4,5 & 0,6 & 1,2 & 6,1 & 10,0 \\
\hline 5,9 & 0,4 & 0,031 & 0,1 & 5,5 & 0,7 & 1,1 & 4,8 & 6,0 \\
\hline 4,0 & 0,2 & 0,079 & 0,2 & 3,6 & 0,5 & 0,9 & 6,0 & 6,5 \\
\hline 4,0 & 0,2 & 0,073 & 0,2 & 3,6 & 0,5 & 0,9 & 6,1 & 8,0 \\
\hline 3,0 & 0,2 & 0,139 & 0,3 & 2,7 & 0,4 & 0,9 & 7,7 & 8,0 \\
\hline 4,0 & 0,2 & 0,014 & 0,0 & 3,6 & 0,5 & 0,7 & 6,3 & 8,5 \\
\hline 4,0 & 0,2 & 0,038 & 0,1 & 2,7 & 0,4 & 0,7 & 6,4 & 8,0 \\
\hline 3,0 & 0,2 & 0,019 & 0,0 & 2,7 & 0,4 & 0,6 & 5,5 & 6,0 \\
\hline 3,0 & 0,2 & 0,052 & 0,1 & 1,8 & 0,2 & 0,5 & 8,7 & 10,0 \\
\hline 2,0 & 0,1 & 0,064 & 0,2 & 1,8 & 0,2 & 0,5 & 8,8 & 9,5 \\
\hline 3,0 & 0,2 & 0,034 & 0,1 & 1,8 & 0,2 & 0,5 & 4,2 & 5,5 \\
\hline 3,0 & 0,2 & 0,075 & 0,2 & 0,9 & 0,1 & 0,5 & 10,0 & 10,0 \\
\hline 2,0 & 0,1 & 0,048 & 0,1 & 1,8 & 0,2 & 0,5 & 8,0 & 8,0 \\
\hline 1,0 & 0,1 & 0,118 & 0,3 & 0,9 & 0,1 & 0,5 & 11,0 & 11,0 \\
\hline 2,0 & 0,1 & 0,030 & 0,1 & 1,8 & 0,2 & 0,4 & 5,8 & 6,0 \\
\hline 2,0 & 0,1 & 0,026 & 0,1 & 1,8 & 0,2 & 0,4 & 3,5 & 4,5 \\
\hline 2,0 & 0,1 & 0,017 & 0,0 & 1,8 & 0,2 & 0,4 & 7,5 & 8,0 \\
\hline 2,0 & 0,1 & 0,017 & 0,0 & 1,8 & 0,2 & 0,4 & 4,3 & 4,5 \\
\hline 2,0 & 0,1 & 0,011 & 0,0 & 1,8 & 0,2 & 0,4 & 6,0 & 8,0 \\
\hline 2,0 & 0,1 & 0,008 & 0,0 & 1,8 & 0,2 & 0,4 & 5,3 & 5,5 \\
\hline 2,0 & 0,1 & 0,008 & 0,0 & 1,8 & 0,2 & 0,4 & 5,5 & 6,0 \\
\hline 2,0 & 0,1 & 0,006 & 0,0 & 1,8 & 0,2 & 0,4 & 4,5 & 5,0 \\
\hline 2,0 & 0,1 & 0,006 & 0,0 & 1,8 & 0,2 & 0,4 & 4,3 & 5,5 \\
\hline 2,0 & 0,1 & 0,005 & 0,0 & 0,9 & 0,1 & 0,3 & 5,8 & 6,0 \\
\hline 1,0 & 0,1 & 0,011 & 0,0 & 0,9 & 0,1 & 0,2 & 7,0 & 7,0 \\
\hline 1,0 & 0,1 & 0,010 & 0,0 & 0,9 & 0,1 & 0,2 & 5,5 & 5,5 \\
\hline 1,0 & 0,1 & 0,008 & 0,0 & 0,9 & 0,1 & 0,2 & 6,0 & 6,0 \\
\hline 1,0 & 0,1 & 0,007 & 0,0 & 0,9 & 0,1 & 0,2 & 6,0 & 6,0 \\
\hline 1,0 & 0,1 & 0,004 & 0,0 & 0,9 & 0,1 & 0,2 & 4,0 & 4,0 \\
\hline 1,0 & 0,1 & 0,003 & 0,0 & 0,9 & 0,1 & 0,2 & 4,5 & 4,5 \\
\hline 1,0 & 0,1 & 0,003 & 0,0 & 0,9 & 0,1 & 0,2 & 4,0 & 4,0 \\
\hline 1,0 & 0,1 & 0,003 & 0,0 & 0,9 & 0,1 & 0,2 & 3,0 & 3,0 \\
\hline 1,0 & 0,1 & 0,003 & 0,0 & 0,9 & 0,1 & 0,2 & 3,0 & 3,0 \\
\hline 1,0 & 0,1 & 0,002 & 0,0 & 0,9 & 0,1 & 0,2 & 5,5 & 5,5 \\
\hline 1,0 & 0,1 & 0,002 & 0,0 & 0,9 & 0,1 & 0,2 & 4,0 & 4,0 \\
\hline 1606 & 100 & 39,92 & 100 & 777 & 100 & 300 & 7,4 & - \\
\hline
\end{tabular}

Erythroxylum deciduum A.St.-Hil.

Eugenia uruguayensis Cambess.

Allophylus edulis (A.St.-Hil. et al.) Hieron. ex

Niederl.

Lonchocarpus campestris Mart. ex Benth.

Eugenia pyriformis Cambess.

Handroanthus albus (Cham.) Mattos

Styrax leprosus Hook. \& Arn.

Myrcia selloi (Spreng.) N.Silveira

Xylosma prockia (Turcz.) Turcz.

Myrciaria delicatula (DC.) O.Berg

Blepharocalyx salicifolius (Kunth) O.Berg

Solanum pseudoquina A.St.-Hil.

Chionanthus filiformis (Vell.) P.S.Green

Baccharis uncinella DC.

Campovassouria cruciata (Vell.) R.M.King \&

H.Rob. (Vell.) R.M.King \& H.Rob.

Myrsine umbellata Mart.

Symplocos uniflora (Pohl) Benth.

Acca sellowiana (O.Berg) Burret

Ilex taubertiana Loes.

Nectandra megapotamica (Spreng.) Mez

Strychnos brasiliensis Mart.

Baccharis dentata (Vell.) G.M.Barroso

Baccharis semiserrata DC.

Aureliana wettsteiniana (Witasek) Hunz. \&

Barboza

Symphyopappus compressus (Gardner) B.L.

Rob.

Ilex dumosa Reissek

Scutia buxifolia Reissek

$\begin{array}{lllllll}1606 & 100 & 39,92 & 100 & 777 \quad 100 & 300 & 7,4\end{array}$ AD: absolute density (ind./ha); RD: relative density (\%); AF: absolute frequency (\%); RF: relative frequency (\%); ADo: absolute dominance
$\left(\mathrm{m}^{2} / \mathrm{ha}\right) ;$ RDo: relative dominance (\%); IV: importance value; H: mean height of each species (m); Hx: maximum height of each species (m).

In the TWINSPAN analysis, the floristic composition of the study area was divided into three groups (Figure 3). In the first division, it segregated the secondary forest area (Group 1) and the border area with predominance of pioneering species next to the pine (Pinus taeda) forest plantation (Group 2). In the second division, two groups within the secondary forest with low floristic dissimilarity, with Jacaranda puberula of the greatest importance value, emerged (Table 3): Group 1.1 had Casearia decandra as the predominant indicator species in the shaded lower stratum, whereas Group 1.2 had such pioneer indicator species as Zanthoxylum rhoifolium Lam. and Vernonanthura discolor. In terms of spatial distribution, Group 2 was limited to the border area, where an expansion of pioneer forest vegetation, favored by the space between the forest and the pine forest plantation, was possible. The other groups (2.1 and 2.2) were limited by the edge areas: the roadside and forest border. The soils did not show influence on the spatialization of the floristic groups due to the low pedological variation among the sampled plots (Figure 3). 


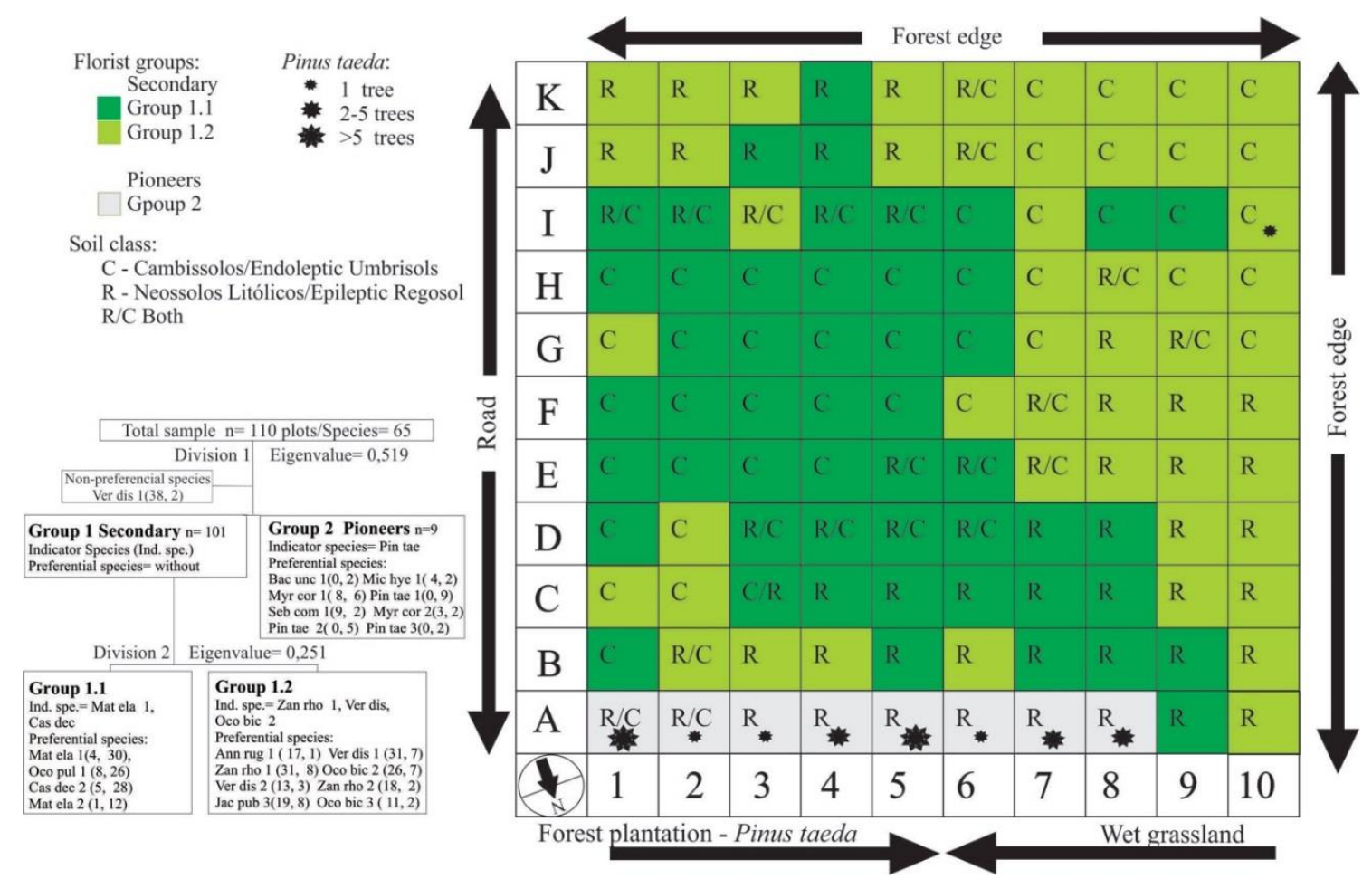

Figure 3. Dendrogram of the classification of ecological groups and indicator species. The first three letters represent name of the genus and specific epithet, as shown in Table 2.

Figura 3. Dendrograma da classificação dos grupos ecológicos e espécies indicadoras. As três primeiras letras representam o nome do gênero e epíteto específico das espécies arbóreas, conforme Tabela 2.

Table 3. Phytosociological parameters of the main ecological groups and their totals, with values for the most important species, responsible for approximately $50 \%$ of the IV.

Tabela 3. Parâmetros fitossociológicos total e dos principais grupos ecológicos, com a descrição dos valores das espécies de maior importância, que representam, aproximadamente, 50\% do VI total.

\begin{tabular}{|c|c|c|c|c|c|c|c|c|}
\hline Group & Species & $\mathbf{N}$ & ind.ha & $\mathrm{m}^{2} / \mathrm{ha}$ & $\begin{array}{l}\mathrm{AF} \\
(\%)\end{array}$ & $\begin{array}{l}\mathrm{RF} \\
(\%)\end{array}$ & $\begin{array}{l}\text { IV } \\
(\%)\end{array}$ & IP $(\%)$ \\
\hline \multirow{7}{*}{$\begin{array}{l}\text { Group } 1.1 \\
\text { ( } 53,1 \% \text { of } \\
\text { IV) }\end{array}$} & Jacaranda puberula & 128 & 241,5 & 2,6 & 67,9 & 9,2 & 34,7 & 11,6 \\
\hline & Matayba elaeagnoides & 47 & 88,7 & 6,2 & 56,6 & 7,7 & 30,6 & 10,2 \\
\hline & Casearia decandra & 94 & 177,4 & 1,0 & 69,8 & 9,5 & 25,7 & 8,6 \\
\hline & Ocotea pulchella & 40 & 75,5 & 4,6 & 49,1 & 6,6 & 24,4 & 8,1 \\
\hline & Araucaria angustifolia & 33 & 62,3 & 4,5 & 45,3 & 6,1 & 22,6 & 7,5 \\
\hline & Calyptranthes concinna & 55 & 103,8 & 1,7 & 66,0 & 9,0 & 21,5 & 7,2 \\
\hline & Total & 685 & 1292 & 38,6 & 737,7 & 100,0 & 300,0 & 100,0 \\
\hline \multirow{7}{*}{$\begin{array}{l}\text { Group } 1.2 \\
(55,9 \% \text { of } \\
\text { IV) }\end{array}$} & Jacaranda puberula & 198 & 412,5 & 4,5 & 81,3 & 9,1 & 44,0 & 14,7 \\
\hline & Ocotea bicolor & 132 & 283,3 & 4,2 & 75,0 & 8,4 & 35,2 & 11,7 \\
\hline & Vernonanthura discolor & 49 & 102,1 & 5,5 & 64,6 & 7,2 & 27,5 & 9,2 \\
\hline & Morta & 59 & 122,9 & 2,8 & 62,5 & 7,0 & 21,4 & 7,1 \\
\hline & Araucaria angustifolia & 32 & 66,7 & 4,4 & 52,1 & 5,8 & 21,3 & 7,1 \\
\hline & Zanthoxylum rhoifolium & 63 & 131,3 & 1,4 & 64,6 & 7,2 & 18,3 & 6,1 \\
\hline & Total & 864 & 1800 & 37,6 & 893,8 & 100,0 & 300,0 & 100,0 \\
\hline \multirow{7}{*}{$\begin{array}{l}\text { Group } 2 \\
(75,3 \% \text { of } \\
\text { IV) }\end{array}$} & Pinus taeda & 27 & 300,0 & 14,5 & 100,0 & 25,7 & 133,7 & 44,6 \\
\hline & Myrsine coriacea & 13 & 144,4 & 0,8 & 66,7 & 17,1 & 38,7 & 12,9 \\
\hline & Clethra scabra & 9 & 100,0 & 0,3 & 11,1 & 2,9 & 16,6 & 5,5 \\
\hline & Sebastiania commersoniana & 4 & 44,4 & 0,8 & 22,2 & 5,7 & 14,9 & 5,0 \\
\hline & Araucaria angustifolia & 1 & 11,1 & 1,6 & 11,1 & 2,9 & 12,1 & 4,0 \\
\hline & Calyptranthes concinna & 3 & 33,3 & 0,6 & 11,1 & 2,9 & 9,7 & 3,2 \\
\hline & Total & 73 & 811,1 & 20,4 & 388,9 & 100,0 & 300,0 & 100,0 \\
\hline
\end{tabular}

$\mathrm{N}$ : number of individuals; AF: absolute frequency; RF: relative frequency; IV: importance value; IP: importance percentage.

FLORESTA, Curitiba, PR, v. 48, n. 4, p. 483-492, out/dez. 2018

Scipioni. M. C. et.al.

ISSN eletrônico 1982-4688

DOI: $10.5380 /$ rf.v48i4.51281 
Canopy opening and basal area were consistent parameters for differentiation of the groups in the secondary (Groups 1.1 and 1.2) and pioneer vegetation (Group 2), respectively, with higher values for the basal area and lesser values for the canopy opening. The mean diameter and height values showed no differences among the groups, whereas, the density values were distinctive for the three groups, with high values for Group 1.2, in the intermediate process of succession, and a smaller number of trees in Group 2, dominated by shrubby vegetation (Table 4).

Table 4. Phytosociological parameters and canopy cover of floristic groups in the study fragment of the Araucaria Forest, municipality of Curitibanos, state of Santa Catarina, Brazil.

Tabela 4. Parâmetros fitossociológicos e abertura de dossel de grupos florístico em um fragmento de Floresta Ombrófila Mista, em Curitibanos, Santa Catarina, Brasil.

\begin{tabular}{llllll}
\hline \multirow{2}{*}{ Variables } & Group 1.1 & Group 1.2 & Group 2 & \multicolumn{2}{l}{ ANOVA } \\
\cline { 4 - 6 } & $\boldsymbol{n = 5 3}$ & $\boldsymbol{n = 4 8}$ & $\boldsymbol{n}=\mathbf{9}$ & $\boldsymbol{p}$ \\
\hline Canopy opening (\%) & $19,0 \pm 6,8^{\mathrm{a}}$ & $21,1 \pm 8,2^{\mathrm{a}}$ & $29,5 \pm 12,9^{\mathrm{b}}$ & 6,775 & 0,002 \\
Basal area/ha & $38,5 \pm 17,9^{\mathrm{a}}$ & $37,5 \pm 13,6^{\mathrm{a}}$ & $20,4 \pm 11,8^{\mathrm{b}}$ & 5,253 & 0,007 \\
Trees/ha & $1292 \pm 518^{\mathrm{a}}$ & $1800 \pm 591^{\mathrm{b}}$ & $811 \pm 379^{\mathrm{c}}$ & 18,309 & 0,000 \\
Mean diameter (cm) & $16,0 \pm 4,0$ & $13,6 \pm 2,1$ & $15,3 \pm 5,5$ & 6,139 & 0,003 \\
Average height $(\mathrm{m})$ & $7,8 \pm 1,4$ & $7,2 \pm 1,1$ & $6,9 \pm 1,4$ & 3,210 & 0,044 \\
\hline
\end{tabular}

Values are means \pm standard deviation of $n$ samples of each floristic group. In cases when the $F$ and $p$ tests indicated significant differences between the groups, averages followed by the same letter did not differ significantly from each other in the Tukey test $(\alpha=0,05)$, while values without letters were not significant.

\section{DISCUSSION}

Comparison of our study fragment and other surveys of the MOF in the advanced secondary stage showed the same floristic patterns for the richest families, Myrtaceae and Lauraceae (SCHAAF et al., 2006; SILVA et al., 2012; HIGUCHI et al, 2013). However, our study also showed that the forest edge, with the Asteraceae standing out as pioneer species, was characterized by an increase in the number of species typical of open areas (GUIDINI et al., 2014). The presence of this family at forest edges is conditioned by a greater canopy opening and luminosity in the understory, associated with the succession stage of the pioneer tree component with the low basal area (SIMINSKI et al., 2013). Guidini et al. (2014), evaluating the forest edge effects, also confirmed the presence of Asteraceae and Pinus taeda in that sector, occupying space of the initial succession species and those classified as pioneers.

Information on forest edge effects of forest fragments in contact with commercial Pinus plantations is of great importance, especially for the subtropical regions, such as southern and southeastern Brazil, where areas of commercial forest plantations dominate natural habitats (ROSA et al., 2015). The occurrence of Pinus taeda within the MOF forest fragments was low. The colonization capacity of Pinus taeda, impeded by hydromorphic soils and shade environments, is not restricted by the low fertility of litholical soils. But its clustering with pioneer species at the edge of forest fragments, highlights its potential to substitute native species in the process of regeneration, by colonizing areas with greater luminosity and open canopies, such as clearings and areas in the initial stages of succession (GUIDINI et al., 2014).

Analyses of differences in species diversity of the regenerative component in the OMF in relation to distance from the forest edge showed, according to Rosa et al. (2015), a greater diversity in the first 20 meters. In our observations, the pioneer arboreal component, composed for the most part by the genus Baccharis (Asteraceae), is restricted to the first $10 \mathrm{~m}$ of the forest fragment associated with Pinus taeda.

The diversity values for the MOF domain in our study, compared to those cited by Higuchi et al. (2016), may be considered as intermediary. In those studies, values higher than $H^{\prime}=3,5$ and $J=0,80$ indicate, respectively, greater diversity and lower ecological dominance, with the lower values showing a degree of anthropogenic intervention.

Silva et al. (2012) recorded 80 species in the MOF areas they sampled, with the greater species richness due to a great environmental heterogeneity of their study area along an environmental gradient. Their site was a large forest fragment in an advanced succession stage that included a spring with a stream outflow, and characterized by humidity variations associated with its topography. Our study site, on the other hand, was a small continuous forest fragment with no relief gradient, thus providing no significant variation in the environmental conditions for a greater species richness, even when accounting for the exclusive border tree species becoming important in the formation of a floristic group by changing the light gradient as a result of the border effect. Generally speaking, the smaller the biologically altered forest fragments, the lower is their floristic and environmental heterogeneity, with the isolation being a defining factor for the reproductive conditions of their 
populations and with effects of a genetic drift over time exacerbated by the lack of connectivity between them (BENNETT et al., 2004; MURCIA, 1995). In order to understand structuring of a fragmented plant community, in addition to the environmental heterogeneity and fragment size, it is important to know the origin of its fragmentation and the containment and expansion limits. Compared to young plants of the understory, adult trees in the interior of the forests how slow response to fragmentation (METZGER et al., 2009), but they may be present at the edge of the fragment in cases of linear cuts through the forest core for road openings.

\section{CONCLUSIONS}

- Neossolo Litólico and Cambissolo Húmico in flat relief did not show significant pedological and edaphic variation and did not influence structuring of the floristic groups.

- The succession stage and boundary conditions associated with the origin and time of its formation were the main factors in the formation of the floristic groups.

- The species composition of the forest boundary limited by an undisturbed road was similar to that of the forest interior, unlike that of the succession border, dominated by pioneer tree species.

- Pinus taeda was an indicator species for the forest edge with pioneer species, but also detected in the forest interior, attesting to its invasive potential for forest clearings.

\section{REFERENCES}

ALVARES, C. A.; STAPE, J. L.; SENTElHAS, P. C.; DE MORAES GONÇALVES, J. L.; SPAROVEK, G. Köppen's climate classification map for Brazil. Meteorologische Zeitschrift, Stuttgart, v. 22, n. 6, p. 711 - 728 , 2013.

BENNETT, A.; HINSLEY, S.; BELLAMY, P.; SWETNAM, R.; MAC NALLY, R. Do regional gradients in landuse influence richness, composition and turnover of bird assemblages in small woods? Biological Conservation, Montpellier, v. 119, n. 2, p. 191-206, 2004.

CHAO, A.; GOTELli, N.J.; HSIEH, T.C.; SANDER, E.L.; MA, K.H.; COLWELL, R.K.; ELLISON, A.M. Rarefaction and extrapolation with Hill numbers: A framework for sampling and estimation in species diversity studies. Ecological Monographs, Washington, v.84, n.1, p. 45-67, 2014.

CHAO, A.; MA, K. H.; HSIEH, T. C. iNEXT (iNterpolation and EXTrapolation) Online: Software for Interpolation and Extrapolation of Species Diversity. Program and User's Guide published, 2016. Disponível em: <http://chao.stat.nthu.edu.tw/wordpress/software_download/>. Acesso em: 01 out. 2017.

DONAGEMA, G. K.; CAMPOS, D. V. B. DE; CALDERANO, S. B.; TEIXEIRA, W. G. Manual de métodos de análises de solos. $2^{\circ}$ ed. Rio de Janeiro: Embrapa Solos, Centro Nacional de Pesquisas de Solos, 2011.

FLORA DO BRASIL 2020. Jardim Botânico do Rio de Janeiro: Flora do Brasil 2020 em construção. Disponível em: <http://floradobrasil.jbrj.gov.br/>. Acesso em: 13 mai. 2016.

GUIDINI, A. L.; SILVA, A. C.; HIGUCHI, P.; et al. Invasão por espécies arbóreas exóticas em remanescentes florestais no Planalto Sul Catarinense. Revista Árvore, Viçosa, v. 38, n. 3, p. 469 - 478, 2014.

HIGUCHI, P.; SILVA, A. C.; ALMEIDA, J. A. de; BORTOLUZZI, R. L. da C.; MANTOVANI, A.; FERREIRA, T. de S.; SOUZA, S. T. de; GOMES, J. P. SILVA, K. M. Florística e Estrutura do Componente Arbóreo e Análise Ambiental de um Fragmento de Floresta Ombrófila Mista Alto-Montana no Município de Painel, SC. Ciência Florestal, Santa Maria, v. 23, n. 1, p. 153 - 164, 2013.

HIGUCHI, P.; SILVA, A. C. DA; FERREIRA, T. de S.; SOUZA, S. T. de; GOMES, J. P.; SILVA, K. M. da; SANTOS, K. F. dos; BERNDT, E. J.; SOUZA JUNIOR, J. de O.; GOIS, D. T.; WEIDUSCHAT, F. Florística e Estrutura do Componente Arbóreo e Relação com Variáveis Ambientais em um Remanescente Florestal em Campos Novos - SC. Ciência Florestal, Santa Maria, v. 26, n. 1, p. 35 - 46, 2016.

IBGE. Manual Técnico da Vegetação Brasileira. $2^{\circ}$ ed. Rio de Janeiro: Instituto Brasileiro de Geografia e Estatística - IBGE, 2012.

LEITE, P. F. Contribuição ao conhecimento fitoecológico do Sul do Brasil. Ciência e Ambiente, Santa Maria, v. 24, p. 51-73, 2002.

LEMMON, P. A. A spherical densiometer for estimating forest overstory density. Forest Science, Bethesda, v. 2, n. 4, p. 314 - 320, 1956.

FLORESTA, Curitiba, PR, v. 48, n. 4, p. 483-492, out/dez. 2018

Scipioni. M. C. et.al.

ISSN eletrônico 1982-4688

DOI: $10.5380 /$ rf.v48i4.51281 
MCCUNE, B.; MEFFORD, M. J. PC-ORD: Multivariate Analysis of Ecological Data. , 2011. Gleneden Beach: MjM Software.

METZGER, J.; MARTENSEN, A.; DIXO, M.; et al. Time-lag in biological responses to landscape changes in a highly dynamic Atlantic forest region. Biological Conservation, Montpellier, v. 142, n. 6, p. 1166 - 1177, 2009.

MUELLER-DOMBOIS, D.; ELLEMBERG, H. Aims and methods of vegetation ecology. New York: Willey and Sons, 2002.

MURCIA, C. Edge effects in fragmented forests: implications for conservation. Trends in ecology \& evolution, Londres, v. 10, n. 2, p. 58 - 62, 1995.

REZNIK, G.; PIRES, J. P. DE A.; FREITAS, L. Efeito de bordas lineares na fenologia de espécies arbóreas zoocóricas em um remanescente de Mata Atlântica. Acta Botanica Brasilica, Belo Horizonte, v. 26, n. 1, p. 65 $73,2012$.

ROSA, A. D.; SILVA, A. C.; HIGUCHI, P.; GUIDINI, A. L.; SPIAZZI, F. R.; NEGRINI, M.; ANSOLIN, R. D.; BENTO, M. A.; GONÇALVES, D. A.; FERREIRA, T. de S. Diversidade e guildas de regeneração de espécies arbóreas na borda de uma floresta nativa em contato com plantio de Pínus. Floresta, Curitiba, v. 45, n. 2 , p. 273 280, 2015.

SANTOS, H. G.; ALMEIDA, J. A.; OLIVEIRA, J. B. de; LUMBRERAS, J. F.; ANJOS, L. H. C. dos; COELHO, M. R.; JACOMINE, P. K. T.; CUNHA, T. J. F.; OLIVEIRA, V. Á. de. Sistema Brasileiro de Classificação de Solos. $3^{\mathrm{a}}$ ed. Rio de Janeiro: Empresa Brasileira de Pesquisa Agropecuária, Centro Nacional de Pesquisa de Solos, 2013a.

SANTOS, R. D.; LEMOS, R. C. L.; SANTOS, H. G.; KER, J. C.; ANJOS, L. H. C.; SHIMIZU, S. H. Manual de descrição e coleta de solo no campo: revisada e ampliada. $6^{a}$ ed. Viçosa: SBCS, 2013b.

SCHAAF, L. B.; FILHO, A. F.; GALVÃO, F.; SANQUETTA, C. R.; LONGHI, S. J. Modificações FlorísticoEstruturais de um Remanescente de Floresta Ombrófila Mista Montana no Período entre 1979 e 2000. Ciência Florestal, Santa Maria, v. 16, n. 3, p. 271 - 291, 2006.

SIMINSKI S.; FANTINI, A. C.; REIS, M. S. Classificação da vegetação secundária em estágios de regeneração da Mata Atlântica em Santa Catarina. Ciência Florestal, Santa Maria, v. 23, n. 3, p. 369 - 378, 2013.

SILVA, A. C. DA; HIGUCHI, P.; AGUIAR, M. D. DE A.; et al. Relações Florísticas e Fitossociologia de uma Floresta Ombrófila Mista Montana em Lages, Santa Catarina. Ciência Florestal, Santa Maria, v. 22, n. 1, p. 193 $-206,2012$.

VIBRANS, A. C.; MCROBERTS, R. E.; MOSER, P.; NICOLETTI, A. L. Using satellite image-based maps and ground inventory data to estimate the area of the remaining Atlantic forest in the Brazilian state of Santa Catarina. Remote Sensing of Environment, v. 130, p. 87 - 95, 2013.

WILDNER, W.; CAMOZZATO, E.; TONIOLO, J. A.; et al. Mapa geológico do estado de Santa Catarina, Porto Alegre: CPRM, escala 1:500.000, 2014. Programa Geologia do Brasil. Subprograma de Cartografia Geológica Regional. 